\title{
PENGARUH SIKAP DAN PERAN ORANG TUA TERHADAP PERGESERAN BAHASA LUWU DI KALANGAN ANAK-ANAK PADA MASYARAKAT LUWU KOTA PALOPO
}

\author{
${ }^{1}$ Jumharia Djamareng, ${ }^{2}$ Jufriadi \\ 1,2IAIN Palopo \\ Jl. Agatis, Balandai, Kota Palopo, Sulawesi Selatan \\ E-mail: 1]umharia@yahoo.com, ${ }^{2}$ jufriadi@iainpalopo.ac.id
}

\begin{abstract}
:
This study aims to describe the condition of Luwu language shift among children in Palopo city. Furthermore, it was seen whether the attitude factor and the role of parents affect the use of Luwunese. To answer these issues, the researchers involved the societies of Palopo who live in the districts of Wara, East Wara, Bara, and Tellu Wanua as the population of this study. Then, this study involved 120 samples consisting of; 1) 60 children around 6 - 12 year old (primary school age) in which 10 children were chosen from each district; and 2) 60 older people (30-50 years old, married). Data collecting techniques were in forms of observation, questionnaires and interviews through note taking and recording as the research instruments. The findings showed that the language shift occurred among children in Palopo city based on the data percentage analysis obtained from the questionnaires. The use of Luwunese by parents was the roles of parents in providing significant influences on the language shift occurring in children shown by the percentage calculation where almost the respondents showed a lack of Luwunese use by children and parents in their family interactions. The parents' positive attitude towards the use of Luwunese indicated by the questionnaire percentage had no impact on Luwunese preservation; whereas, the Luwunese shift occurred in Palopo city.
\end{abstract}

Keywords: Attitudes, Parents' Roles, Language Shift.

Abstrak

Tulisan ini bertujuan untuk menggambarkan kondisi pergeseran bahasa Luwu dikalangan anak-anak di kota Palopo. Lebih lanjut, akan dilihat apakah faktor sikap dan peran orang tua mempengaruhi penggunaan bahasa Luwu. Untuk menjawab permasalahan tersebut, peneliti menggunakan populasi masyarakat kota Palopo yang berdomisili di kecamatan Wara, kecamatan Wara Timur, kecamatan Wara, kecamatan Bara dan kecamatan Tellu Wanua. Dari sejumlah populasi tersebut, diambil sampel sebanyak 10 anak-anak dari tiap-tiap kecamatan. Jumlah keseluruhan sampel adalah 60 orang usia 6-12 tahun (usia pendidikan dasar), 60 orang tua (30-50 tahun, menikah), total sampel adalah 120 orang. Teknik pengumpulan data yang digunakan adalah observasi, kuesioner dan wawancara yang dilengkapi dengan instrumen penelitian yaitu pencatatan dan rekaman. Hasil penelitian menunjukkan adanya kondisi pergeseran bahasa dikalangan anak-anak di kota Palopo berdasarkan analisis persentase data kuesiner. Penggunaan bahasa Luwu oleh orang tua yang merupakan peran orang-tua memberikan pengaruh yang signifikan terhadap pergeseran bahasa yang terjadi pada anakanak yang ditunjukkan oleh berdasar perhitungan persentase dimana hampir semua jawaban responden menunjukkan kurangnya penggunaan bahasa Luwu oleh anak-anak dan orang tua di ranah keluarga. Adapun sikap positif orang tua terhadap penggunaan bahasa Luwu yang ditunjukkan oleh hasil persentase kuesioner tidak memberi pengaruh pada pemertahanan bahasa Luwu tetapi sebaliknya terjadi pergeseran pada bahasa Luwu di kota Palopo.

Kata kunci: Sikap, Peran Orang tua, Pergeseran Bahasa. 


\section{PENDAHULUAN}

Sebagai masyarakat Indonesia yang sangat menghargai kekayaan budaya dan menjunjung tinggi martabat bangsa, seyogianya memelihara bahasa dan budaya sebagai warisan nenek moyang kepada generasi muda. Fenomena yang terjadi sekarang ini adalah anak-anak sangat jarang yang menggunakan bahasa daerah sebagai bahasa ibunya. Kondisi ini sangat memprihatinkan dimana orang tua tidak lagi menekankan penggunaan bahasa daerah di lingkungan keluarga, mereka lebih bangga bila anak-anak hanya menggunakan bahasa Indonesia maupun bahasa Inggris di rumah. Jika kondisi ini terus berlanjut, tidak menutup kemungkinan bahasa daerah pada akhirnya akan mengalami pergeseran bahkan akan menjadi bahasa yang sudah punah sebagaimana yang sudah terjadi pada beberapa bahasa daerah lainnya yang ada di Indonesia.

Tanggung-jawab masyarakat untuk memelihara dan mempertahankan bahasa daerah sangat dibutuhkan demi menjaga kekayaan bangsa Indonesia. Para pengambil kebijakan dan institusi terkait hendaknya memberikan perhatian terhadap masalah yang dihadapi dan memberikan solusi yang tepat agar kepunahan bahasa dapat dihindari sebisa mungkin. Tentu saja dibutuhkan kerja sama antara pemerintah dan masyarakat untuk melakukan usaha-usaha yang berkenaan dengan pemertahanan bahasa daerah khususnya dan pelestarian budaya pada umumnya. Usaha pemertahanan bahasa dapat dimulai dari lingkup yang lebih kecil yaitu membiasakan penggunaan bahasa daerah dalam lingkungan keluarga terutama pada anakanak. Disinilah peran orang tua dalam memperkenalkan bahasa daerah pada anak-anakdan membiasakan mereka untuk menggunakan dalam berintaraksi dengan anggota keluarga.

Seperti yang dikemukakan oleh Kramsch ${ }^{1}$ sebelumnya bahwa 'identitas' pada dasarnya menjadi alasan utama mengapa orang cenderung tetap menggunakan bahasa daerahnya. Tujuan mereka terutama untuk memperkenalkan siapa dirinya, sebagai individu ataupun kelompok sosial. Studi yang membahas tentang pengaruh identitas diri terhadap pemertahanan bahasa masih sangat terbatas dilakukan oleh ahli bahasa. Akan tetapi penelitian yang berkenaan dengan topic ini sudah pernah dilakukan meskipun dalam jumlah yang masih terbatas.

Penelitian tentang pemertahanan bahasa sekarang ini telah banyak dilakukan di berbagai tempat dimana terdapat masyarakat tertentu yang menuturkan bahasa daerahnya sebagai bahasa minoritas. Fenomena pemertahanan bahasa biasanya terjadi di daerah atau Negara dimana sering didatangi oleh transmigran atau imigran yang ingin memulai hidup baru di

${ }^{1}$ Kramsch, Language and Culture (London: Cambridge University Press, 1998). 
tempat yang baru. Tentu saja, ketika suatu etnik yang pindah ke daerah yang baru , mereka akan menjadi kelompok minoritas di temapat tersebut. Secara normal mereka dapat beradaptasi dengan kebiasaan masyarakat setempat agar mereka dapat diterima menjadi bagian dari penduduk asli tersebut. Jika mereka dapat hidup berdampingan dengan penduduk asli, tidak dapat dipungkiri bahwa mereka secara tidak sadar akan mengadopsi bahasa yang dituturkan oleh penduduk local. Sebagai akibat, mereka akan menjadi bilingual dimana di satu sisi mereka tetap menuturkan bahasa ibunya dan di sisi lain mereka juga menuturkan bahasa local sebagai bahasa yang baru. Kondisi ini tidak dapat dielakkan sebagai pengaruh dari migrasi dimana akulturasi dua bahasa akan terjadi.

Kepunahan bahasa sekarang ini banyak dialami banyak bahasa-bahasa daerah di berbagai daerah. Hal ini tidak dapat dihindari sebagai akibat dari berbagai faktor dan kondisi tertentu meskipun telah dilakukan upaya untuk memelihara bahasa-bahasa tersebut. Terdapat beberapa bahasa punah di sekitar Kalimantan, dimana tinggal 1 dari 50 bahasa yang tidak lagi digunakan. Di Sumatera terdapat 13 bahasa lokal, ada 2 bahasa yang mengalami pergeseran dan 1 diantaranya 1 telah punah. Sementara di Sulawesi, 1 dari 110 bahasa telah hilang dan 36 sementara mengalami proses kepunahan. Di Timor, Flores, Bima and Sumba, terdapat 50 bahasa yang masih bertahan, tetapi ada 8 yang mengalami proses kepunahan. Di Papua dan Halmahera, 56 dari 271 bahasa lokal hampir punah, di Jawa tidak ditemukan kepunahan bahasa.

Banyak faktor yang mempengaruhi pergeseran bahasa Luwu di kota Palopo. Dilihat dari kondisi demografi, penduduk kota Palopo heterogen dimana terdapat banyak suku yang bermukim di sana baik itu sebagai penduduk permananen maupun penduduk yang hanya menetap selama jangka waktu tertentu karena berbagai alasan misalnya pindah tugas (karyawan) dan perniagaan. Adapun suku-suku daerah yang bermukim di kota Palopo adalah masyarakat asli Luwu, suku Bugis (Wajo, Bone, Soppeng, Sidrap), suku Jawa, suku Bali, Sumatera, Flores, Nusa Tenggara, Tionghoa, dan lain lain.

Kondisi inilah yang menyebabkan masyarakat Luwu di kota Palopo lebih banyak menggunakan bahasa Indonesia sebagai alat komunikasi dengan berbagai suku yang ada sehingga mereka jarang lagi menggunakan bahasa Luwu sebagai bahasa pengantar dalam berinteraksi sesama masyarakat Luwu, terutama di kalangan anak-anak dan remaja. Bahasa Luwu hanya dipakai oleh mereka yang dikategorikan kelompok usia dewasa dan lanjut usia itupun penggunaannya terbatas di lingkungan keluarga saja. Kondisi ini sangat memprihantikan dimana anak-anak Palopo tidak memahami bahkan tidak lagi menuturkan bahasa ibu mereka. Penggunaan 


\section{2 | Jumharia Djamareng, Jufriadi}

bahasa ibu dalam ranah keluarga akan membantu mereka untuk terus menggunakan bahasa Luwu dari generasi ke generasi.

Selanjutnya, studi yang berkenaan dengan pergeseran dan pemertahanan bahasa secara berkelanjutan diharapkan mampu mengurangi ancaman terhadap pergeseran bahkan kepunahan yang terjadi di beberapa bahasa daerah. Oleh karena itu dibutuhkan banyak perhatian terhadap penggunaan bahasa lokal di berbagai ranah yang melibatkan institusi terkait seperti Dinas Pendidikan dan Kebudayaan, Dinas Keagamaan.

Penelitian akan difokuskan pada hubungan antara faktor sikap bahasa dan penggunaan bahasa Luwu sebagai faktor yang mempengaruhi pergeseran bahasa yang sedang terjadi diantara masyarakat penutur bahasa Luwu. Sikap bahasa menyangkut bagaimana cara pandang terhadap penggunaan bahasa Luwu dalam berbagai ranah sehingga sikap tersebut bisa positif maupun negative. Sikap positif tentu saja mendorong mereka untuk lebih banyak menggunakan bahasanya dalam berinteraksi sesama interlokutor. Disamping itu penelitian ini juga ingin menunjukkan bagaimana peran orang tua dalam membantu anak-anak menggunakan bahasa daerah dalam ranah keluarga. Frekuensi penggunaan bahasa yang tinggi dapat menyebabkan tingkat kebiasaan penggunaan bahasa tersebut dengan sadar.

Sikap positif juga dapat mempengaruhi status bahasa tersebut. Jika status bahasa daerah masih ditempatkan sebagai kekayaan budaya yang patut dipertahankan maka tentu saja akan mempengaruhi sikap penuturnya. Adanya sikap bangga terhadap penggunan bahasa mereka sendiri akan menunjukkan identitas mereka sebagai masyarakat Luwu. Akan tetapi penelitian ini tidak akan membahas secara mendasar pengaruh identitas dalam pergeseran bahasa. Penelitian tentang tentang sikap bahasa secara otomatis juga akan menggambarkan bagaimana identias diri akan mempengaruhi pergeseran maupun pemertahanan suatu bahasa. Kemungkinan hal ini yang menjadi alasan mengapa studi pergeseran bahasa kaitannya dengan identitas masih sangat terbatas.

\section{KERANGKA TEORETIS}

Beberapa kajian riset sebelumnya dipaparkan secara singkat sebagai berikut:

1) Jumharia Djamereng (20012) Factors Contributing to The Language Maintenance of the Balinese Language in the Transmigrants Community of Sukamaju North Luwu, South Sulawesi. Hasil penelitian menunjukkan bahwa Agama dan budaya yang sangat berkontribusi pada pemertahanan bahasa Bali di daerah transmigrasi sukamaju. Disamping itu juga terdapat 
beberapa factor lain seperti faktor demografi, factor bilingualism, factor usia, pendidikan, mobilitas dan sikap bahasa.

2) Masruddin (2011) Language Shift of Wotunese: Influenced factors and its solution. Hasil penelitian ini menunjukkan bahwa bahasa Wotu telah mengalami pergeseran di kalangan penuturnya di daerah Wotu dimana penutur bahasa ini hanya terbatas pada kelompok generasi pertama atau kalangan lanjut usia. Sementara anak-anak dan remaja jarang sekali (bahkan tidak mengetahui sama sekali ) menggunakan bahasa Wotu dalam lingkup keluarga maupun dalam ranah lainnya seperti di sekolah, pasar dan lain-lain.

3) Lukman (2000) "Pemertahanan Bahasa Warga Transmigrasi Jawa di Wonomulyo-Polmas". Hasil penelitian menunjukkan bahwa masyarakat Jawa pada umumnya menuturkan dua bahasa (bilingual) dimana terdapat 4 pola bilingual yang tuturkan oleh masyarakat Jawa di yaitu; (1) Jawa + bahasa Indonesia, (2) Jawa + bahasa Indonesia + Mandar, (3) Jawa + bahasa Indonesia+ BB, (4) Jawa + bahasa Indonesia + Mandar + BB. Masyarakat Jawa cenderung menggunakan bahasa daerahnya dalam ranah tradisional seperti rumah/keluarga, tetangga, pekerjaan, dan beberapa situasi lainnya.

4) Soemarsono (1993). "Pemertahan Bahasa Melayu Loloan di Bali. Penelitian dilakukan untuk menggambarkan bagaimana masyarakat Melayu yang beragama Islam yang sudah sejak lama bermukim di di Bali tetapi tetap mempertahankan bahasa Melayu Loloan sementara masyarakat asli Pagayaman tetap berbahasa Bali.

5) Moriguchi-McCormick, Y. (1999). Hubungan antara sikap terhadap pemertahanan dan keaksaraan bahasa pertama dikalangan anak-anak Jepang. Japanese children sojourning in the San Francisco Bay Area. United States -- California, University of San Francisco.

6) Chang (1996). Language use and language attitudes among Taiwanese elementary school students in native language instruction programs: A study on language maintenance, language shift, and language planning in Taiwan. Chang melakukan studi tentang penggunaan bahasa dan sikap bahasa dikalangan siswa Sekolah Dasar di Taiwan. Hasil menunjukkan bahwa jumlah respondent yang memiliki sikap positif terhadap bahasa Min Selatan dan bahasa Hakka sangat banyak, dan hal itu berpengaruh pada pemertahanan bahasanya.

Bahasa merupaka milik perorangan dan sosial. Jika bahasa dituturkan secara perorangan artinya orang tersebut berperilaku secara individu seperti individu lainnya. Mereka dapat menuturkan bahasa, dialek, atau ragam bahasa yang sama yaitu menggunakan kode yang sama, dan berhubungan dengan kelompok masyarakar tutur yang sama. Bahasa merupakan milik 


\section{4 | Jumharia Djamareng, Jufriadi}

sosial dalam studi ilmu sosiolinguistik, artinya studi tentang penggunaan bahasa diantara kelompok tutur. "Kelompok" merupakan konsep yang sulit untuk dijelaskan tetapi harus kita pahami. Orang dapat membentuk kelompok berdasar satu atau lebih alas an yaitu; alasan sosial, agama, politik, budaya, keluarga, pekerjaan dan lain lain. Kelompok bias bersifat temporer maupun semi temporer dan tujuan anggotanya dapt diubah. ${ }^{2}$

Bentuk kelompok sosiolingistik secara umum telah mencoba mempelajari studi yang disebut masyarakat tutur. Lyon (1970) dalam Wardhaugh $^{3}$ (2002) menawarkan defenisi yang dia sebut masyarakat tutur yang "sebenarnya"; semua orang yang menggunakan bahasa (atau dialek). Tetapi hal itu kemudian mengubah dari issu menjadi membuat definisi tentang bahasa (dialek) juga sekaligus definisi tentang bahasa masyarakat tutur.

Apa yang diuraikan sebelumnya menyampaikan secara tidak langsung bahwa bahasa akan dituturkan dengan berbeda berdasarkan kategori sosial. Oleh karena itu, organisasi sosial alan mengelompokkan ragam bahasa yang mereka tuturkan . Meskipun ada perbedaan dalam istilah sebagai masyarakat tutur dan pembuat tutur, pada dasarnya mereka memiliki tujuan yang sama., mereka membahas tentang bahasa yang digunakan dalam masyarakat dimana mereka dapat dikelompokkan dalam beberapa kelompok seperti; usia, jenis kelamin, pendidikan, kelas sosial, politik, dan sebagainya.

Kecenderungan masyarakat tutur ketika berinteraksi dengan yang lainnya adalah menuturkan bahasa yang dapat dimengerti satu sama lain atau dengan kata lain bahasa memiliki kejelasan (intelligibility) untuk membuat mereka meraka menjadi bagian dari komunitas tersebut. Hal itu juga membuat mereka tidak bisa menuturkan hanya satu bahasa saja tanpa mengetahui bahasa lainnya. Jika seseorang tidak pernah meninggalkan daerah asalnya, hal ini menyebabkan mereka hanya mengetahui satu bahasa saja yaitu bahasa daerahnya. Dia tidak akan tahu bahasa lain kecuali bahasanya sendiri. Masyarakat seperti itu disebut masyarakat tertutup yang tidak pernah membangun kontak dengan masyarakat tutur lainnya. Biasanya ini disebabkan daerah yang sangat terisolasi atau memang tidak ingin berkomunikasi dengan masyarakat lainya. Oleh karena itu bentuk masyarakat seperti ini dikenal sebagai masyarakat tutur statis yang akan tetap menjaga kondisi sebagai masyarakat monolingual.

Akan tetapi masyarakat yang hanya menuturkan satu bahasa jarang ditemukan sekarang ini, sedikitnya mereka mengetahui dua bahasa meskipun tidak menguasai bahasa kedua sebaik bahasa pertamanya. Sebaliknya, masyarakat tutur terbuka akan membangun hubungan dengan

${ }^{2}$ Wardaugh, Sociolinguistics (Great Britain: Cambridge University Press, 2002).

I3bid. 
masyarakat lainnya dimana mereka akan mengalami kontak bahasa deserta semua fenomena bahasa yang ada. Ada beberapa fenomena bahasa yang terjadi sebagai akibat dari kontak bahasa seperti; diglosia, campur kode, alih kode, interferensi, integrasi, konvergensi, dan pemertahanan bahasa (Chaer dan Leoni) ${ }^{4}$

Sebagaimana masyarakat terbuka yang dapat berinteraksi dengan masyarakat lainnya, mereka akan tahu bahasa lain selain bahasa ibunya. Jika seorang dapat menguasai dua bahasa dia akan dikenali sebagai bilingualism. Istilah bilingualisme masih menjadi debat diantara para ahli linguistic kaintannya dengan penguasaan dua bahasa jika dikaitkan dengan bilingual. Ahli linguistic berpendapat bahwa orang yang dikategorikan sebagai bilingual jika dia menguasai dua bahasa meskipun dia tidak menguasai bahasa kedua sebaik bahasa pertamanya. Ada juga ahli yang berpendapat bahwa seperti apapun kemampuan kedua bahasayang dimiliki, tidak perlu memiliki penguasaan yang sama pada kedua bahasa, orang tersbut sudah bisa dikatakan bilingual.

\section{Pemertahanan Bahasa dan Pergeseran Bahasa}

Jika membahas tentang pergeseran bahasa maka secara otomatis berhubungan dengan pemertahanan bahasa dan kepunahan bahasa. Fenomena bahasa ini adalah kumpulan pengaruh dari adanya pilihan bahasa. Pergeseran bahasa semata-mata berarti penggunaan bahasa yang sangat terbatas baik dari segi penutur maupun tempat dimana dituturkan. Sebaliknya pemertahanan bahasa yaitu jika bahasa tersebut tetap digunakan meskipun dalam kondisi sebagai bahasa minoritas yang jumlah penuturnya tidak banyak karena dituturkan diantara bahasa yang mayoritas. Kepunahan bahasa akan terjadi jika bahasa tesebut tidak ada lagi penuturnya dan posisinya diganti oleh bahasa yang sebagian besar dituturkan oleh masyarakat yang mayoritas.

Pernyataan tersebut didukung oleh Fasold ${ }^{5}$ yang menyatakan bahwa "When a speech community begins to choose a new language in domains formerly reserved for the old one, it may be a sign that language shift is in progress. If the member of a speech community are monolingual and are collectively acquiring another language, then they are obviously maintaining their language-use-pattern. Maintenance, however, is often a characteristic of bilingual or multilingual communities as well. This only happens when the community is diglossic. Another way of saying the same thing is that language-maintaining multilingual communities reserve each language for

\footnotetext{
${ }^{4}$ Abdul Chaer and Leonie Agustina, Sosiolinguistik: Perkenalan Awal (Jakarta: PT. Rineka Cipta, 2004).

${ }^{5}$ R Fasold, The Sociolinguistics of Society (England: Basic Blackwell, Inc., 1984).
} 


\section{6 | Jumharia Djamareng, Jufriadi}

certain domains with very little encroachment of one language on the domains of the others.

Pada kenyataannya, istilah 'maintenance' dan 'shift' yang diajukan oleh artikel yang pertama kali ditulis oleh Joshua Fishman in 1964. Pemertahanan bahasa berarti penggunaan bahasa yang berkelanjutan dalam menghadapi persaingan dengan bahasa yang lebih banyak memiliki kekuatan secara sosial dan regional. Sebaliknya, istilah pergeseran bahasa artinya pergantian satu bahasa oleh bahasa lainnya sebagai bahasa utama dalam berkomunikasi dan sosialisasi dalam masyarakat. Adapun istilah kepunahan bahasa digunakan jika komunitas pengguna bahasa itu tinggal satu bahkan tidak ada lagi. Penelitian tentang gejala bahasa tersebut telah lama dilakukan oleh Fishman's (1966) dan Kloss (1966) yang memberikan solusi dan upayaupaya untuk pemertahanan bahasa. Dua studi klasik tentang pergeseran bahasa dilakukan oleh Nancy Dorian (1981) dan Susan Gal (1979) pada bahasa Gael di Skotlandia Timur bagian Laut yang bergeser dari bahasa Hongaria ke bahasa Jerman pada komunitas Oberwart, Austria. Hingga sekarang, banyak studi yang fokus pada issu-issu bahasa tersebut sebagai lingkup sosiolinguistik macro (Mesthrie, et, all) ${ }^{6}$

\section{Faktor-Faktor yang Berpengaruh pada Pergeseran Bahasa}

Ada beberapa faktor yang dapat mempengaruhi bahasa dapat dipertahankan oleh penuturnya. Faktor-faktor tersebut juga menjadi alasan mengapa bahasa dapat bergeser atau sebaliknya dapat dipelihara. Faktor yang paling jelas yang dapat mempengaruhi pergeseran bahasa adalah sikap penutur terhadap bahasa daerahnya sendiri. Hal ini dibutikan oleh berbagai studi yang mengkaji bagaimana sikap dapat mempengaruhi penggunaan bahasa daerah secara berkelanjutan dari generasi ke generasi. Pada umumnya, suatu daerah dimana struktur masyarakatnya multi etnis maka kecenderungan menggunakan satu bahasa (bahasa nasional) sebagai alat interaksi diantara para masyarakat yang berasal dari berbagai macam suku. Penggunaan bahasa yang dapat berfungsi sebagai media komunikasi secara otomatis akan mengurangi tingkat penggunaan bahasa daerah masingmasing secara konstan.

Apa yang dibahas oleh Holmes nampaknya jelas bahwa pergeseran bahasa secara normal terjadi dalam kelompok bahasa minoritas yang berpindah ke tempat yang jauh dari tanah kelahirannya. Masyarakat ini cenderung sering menggunakan bahasa mereka dengan tujuan untuk menunjukkan identitas diri. Oleh karena itu mereka juga lebih menyukai tinggal bersama secara berkelompok untuk memudahkan mereka untuk 2000).

${ }^{6}$ Mestrhie R, Introducing Sociolinguistics (Edinburgh: Edinburgh University Press, 
selalu bertemu dan juga mempertahankan bahasanya karena digunakan sehari-hari untuk berinteraksi satu sama lain.

Faktor lain yang mempengaruhi pemertahanan bahasa adalah mobilitas atau frekuensi kunjungan ke tanah kelahiran atau ke daerah lain baik yang lokasinya terdapat mayoritas suku mereka maupun yang minoritas bermukim di daerah tersebut. Arus imigran atau pengujung baru secara tetap membutuhkan penggunaan bahasa yang terus berlanjut. Sebagai contoh imigran Polynesia dari Niue, Tokelau, Tonga, dan tiba di New Zealand secara teratur. Orang Polinesia New Zealand memberikan keramahan kepada mereka. Dan pengunjung baru tentu saja memberikan input kebahasaan bagi masyarakat New Zealand. Prospek perjalanan tetap "mudik" ke tanah kelahiran memberikan motivasi yang sama untuk mempertahankan bahasa asalnya. Contohnya orang Samoa di New Zealand, selalu berharap untuk pulang ke daerah asalnya sebagai tanggung jawab terhadap keluarga. Imigran Yunani juga bepergian kembali ke Yunani sebagai prioritas utama bagi mereka dan anak-anaknya. Tindakan ini jelas menjadi alasan yang kuat untuk mempertahankan kemahiran dalam berbahasa Yunani. ${ }^{7}$

Holmes ${ }^{8}(1991)$ juga menambahkan faktor lain yaitu dukungan institusi yang memberikan perbedaan antara sukses dan gagal dalam mempertahankan kelompok bahasa minoritas. Pendidikan, hukum, dan administrasi, agama dan media adalah ranah yang penting yang berkenaan dengan masalah ini. Kelompok minoritas yang memberdayakan institusi ini untuk mendukung berhasilnya upaya untuk pemertahanan bahasa. Jika pemerintah suatu negara bertekad untuk menyelamatkan atau memelihara bahasa daerah, memberikan peluang untuk melegalisasikan penggunaan bahasa daerah dalam semua ranah tersebut.

Berbeda dengan apa yang diungkapkan oleh Romaine dalam Holmes (1992) 9 yang menyebutkan "sikap" sebagai salah satu faktor yang berpengaruh dalam pada pergeseran bahasa secara terpisah. Dia menyatakan bahwa status bahasa yang berfungsi secara international dapat berkontribusi memberikan sikap positif seperti yang terjadi pada orang-orang Perancis di Kanada dan Amerika Serikat. Hal ini disebabkan karena bahasa Perancis memiliki status yang tinggi secara internasional. Contohnya orang Perancis Amerika di Maine yang menganggap bahasa Perancis adalah bahasa yang baik untuk diketahui karena memiliki prestise internasional. Imigran Yunani merasa bangga bisa berkontribusi pada pada pemertahanan bahasa Yunani pada filsafat dan budaya barat, kesadaran ini penting bagi bahasa mereka untuk menolak peralihan bahasa ke bahasa Inggris.

${ }^{7}$ Holmes J, Bilingualism (USA: Blackwell Publisher Ltd, 1989).

8 Ibid., hal 100

${ }^{9}$ Ibid., hal 103 


\section{8 | Jumharia Djamareng, Jufriadi}

Jika Holmes (1992) menyatakan bahwa sikap memegang peranan yang penting dalam pemertahanan bahasa, sebaliknya, Romaine ${ }^{10}$ (1989) menyebutkan bahwa identifikasi pada bahasa dan sikap positif terhadap bahasa tidak menjamin bahasa tersebut dapat bertahan. Dia memberikan bukti untuk mendukung pendapatnya sebagaimana yang dia temukan Irlandia, dimana perlunya menggunakan bahasa Inggris telah mengalahkan antipasti terhadap bahasa Inggris maupun penuturnya. Adopsi bahasa Inggris oleh orang Irlandia adalah kasus pergeseran bahasa yang tidak disertai sikap baik terhadap bahasa Irlandia (lihat Macnamara 1973). Perbedaan pendapat yang diungkapkan oleh kedua ahli tersebut tergantung dari masyarakat tempat penelitian mereka berlangsung. Tumbuhnya sikap positif terhadap penggunaan bahasa bisa saja dipengaruhi oleh status bahasa itu sendiri di dunia. Disamping itu, latar belakang sejarah yang mendukung orang Perancis sangat menjunjung tinggi bahasanya sehingga mereka selalu menggunakan bahasa Perancis ketika mereka berkunjung ke negara lain

\section{METODE PENELITIAN}

Kota Palopo ini dulunya bernama Ware yang dikenal dalam Epik La Galigo. Nama "Palopo" ini diperkirakan mulai digunakan sejak tahun 1604, bersamaan dengan pembangunan masjid Jami' Tua. Kata "Palopo" ini diambil dari dua kata bahasa Bugis-Luwu. Artinya yang pertama adalah penganan ketan dan air gula merah dicampur. Arti yang kedua dari kata Palo'po adalah memasukkan pasak ke dalam tiang bangunan. Dua kata ini ada hubungannya dengan pembangunan dan penggunaan resmi masjid Jami' Tua yang dibangun pada tahun 1604.

Penelitian ini bersifat deskriptif kualitatif yang dilaksanakan di Kota Palopo. Populasi yang digunakan adalah seluruh masyarakat yang berusia 612 tahun dan orang tua yang berusia 30-50 tahun yang merupakan warga asli Luwu yang menetap di beberapa kecamatan di Kota Palopo. Sampel diambil dengan menggunakan multi stage sampling dimana dipilih 10 orang dari 5 kecamatan yang ada sehingga total sampel yang terpilih sebanyak 120 orang dengan rincian 60 orang sampel usia anak-anak dan 60 orang sampel usia orang tua. Data penelitian diperoleh melalui observasi, angket, dan wawancara yang sebelumnya telah diuji validitas dan reliabilitasnya.

\section{PENGARUH SIKAP TERHADAP PERGESERAN BAHASA LUWU}

Sikap sebagai salah satu faktor yang sangat berpengaruh pada pemertahan maupun pergeseran bahsa. Banyak penelitian yang berkenaan

10 S Romaine, Bilingualism (Massavhusetts: Blackwell Publisher Ltd, 1989). 
dengan fenomena bahasa tersebut menyimpulkan bahwa sikap berpengaruh signifikan terhadap pemertahanan bahasa karena sikap berkaitan erat dengan simbol identitas diri atau etnis suatu kelompok masyarakat. Ketika sekelompok masyarakat sangat menjunjung tinggi rasa kesukuannya maka mereka cenderung menggunakan bahasa daerahnya sebagai simbol identitas diri. Begitu pula yang terjadi pada masyarakat Palopo dimana sikap mereka terhadap bahasa daerah sangat positif. Hal ini sesuai denga teori yang diajukan oleh Holmes (1992) yang menyatakan bahwa "Ketika suatu bahasa dianggap menjadi simbol identitas etnis, pada umumnya akan bertahan lebih lama. Dukungan sikap positif untuk terus berusaha menggunakan bahasa minotitas di berbagai ranah, dan hal ini akan membantu orang menghindari tekanan dari kelompok mayoritas mengalihkan bahasa mereka."

Berdasarkan hasil perhitungan persentase dimana data menunjukkan bahwa sikap orang tua tidak berpengaruh terhadap pergeseran bahasa Luwu di kalangan anak-anak di kota Palopo. Meskipun hasilnya menunjukkan sikap positif orang tua terhadap penggunaan bahasa Luwu tetapi tidak mempengaruhi keinginan mereka menggunakan bahasa tersebut ketika berkomunikasi dengan anak-anak mereka.

Sikap positif mereka tidak mendukung penggunaan bahasa daerah dalam ranah keluarganya. Sebaliknya mereka lebih banyak menggunakan bahasa Indonesia dialek Palopo ketika bercakap-cakap dengan anak-anaknya. Fakta ini ditunjukkan oleh data kuesioner dimana hampir semua jawaban mereka mendukung penggunaan bahasa Luwu dalam ranah pendidikan, sosial, agama, dan budaya meskipun pada kenyataannya mereka jarang menggunakan bahasanya. Faktor lain yang menyebabkan kondisi tersebut adalah karena mereka dituntut untuk menggunakan bahasa Indonesia sebagai bahasa untuk berinteraksi dengan berbagai etnis yang menetap di kota Palopo.

Adapun alasan mereka menggunakan bahasa Luwu kepada anakanaknya karena dianggap lebih mudah memberi pengertian jika menggunakan bahasa Indonesia karena anak-anak sudah terbiasa dengan bahasa itu. Apalagi dalam pergaulan atau bermain dan belajar dengan kawankawannya, mereka memang menggunakan bahasa Indonesia, walau ada sedikit dialek Palopo yang digabung dalam bahasa itu.

Selanjutnya orang tua juga menunjukkan sikap positif terhadap penggunaan bahasa daerah yang dicampur bahasa Indonesia dala ranah agama.

"saya setuju jika bahasa Luwu atau "Tae" digunakan ketika ceramah di mesjid atau acara budaya, supaya bahasa Tae bisa bertahan dan bisa dilestarikan. Generasi muda yang harus melestarikan bahasa daerah 
dengan upaya apapun. Melestarikan budaya itu baik untuk masyarakat Luwu."(hasil wawancara, Oktober 2015)

Pernyataan responden ini menunjukkan bahwa sikap mereka sangat positif dalam menanggapi penggunaan bahasa daerah oleh pemuka agama atau uztad ketika ceramah di mesjid. Akan tetapi penelitian ini tidak ingin mengkaji faktor agama sebagai variable dalam penelitian ini. Meskipun agama menjadi faktor penting dalam pemertahanan bahasa dalam beberapa penelitian lainnya. Seperti hasil penelitian yang ditemukan oleh Djamereng (2012) ${ }^{11}$ dimana dia menemukan bahwa agama Hindu sebagai agama yang dianut oleh masyarakat Bali di daerah Transmigrasi Sukamaju Kabupaten Luwu Utara, merupakan faktor yang sangat signifikan dalam mempertahankan bahasa Bali di daerah transmigrasi meskipun bahasa tersebut menjadi bahasa minoritas di daerah tersebut.

Sikap positif orang tua terhadap penggunaan bahasa daerah pada ranah budaya juga ditunjukkan pada table 22 dimana terdapat $70 \%$ yang setuju dengan pernyataan tersebut. Budaya sebagai salah satu factor yang penting dalam pemertahan bahasa. Adat istiadat yang sangat dipegang teguh oleh masyarakat Luwu dimana sejarah kerajaan Luwu pada jaman dulu yang diperintah oleh Datuk Luwu secara turun temurun sangat menjunjung tinggi nilai-nilai budaya sampai sekarang ini. Ini ditandai dengan pelaksanaan aktifitas-aktifitas budaya, salah satunya adalah "maccera tasik" yang banyak mengandung muatan-muatan lokal daerah ini.

Hasil penelitian ini relevan dengan penelitian yang dilakukan oleh Tom $(2003)^{12}$ dimana dia menguji pemertahanan bahasa Slovania di Carinthia (Austria). Dia menguji tiga parameter seperti; penggunaan bahasa, kompetensi bahasa, dan sikap bahasa. Dia juga menguji hasil tambahan yang diperoleh dari kelompok usia yang berbeda. Hasilnya menunjukkan bahwa jika suatu bahasa dapat bertahan, penutur yang muda pasti memiliki sikap yang layak terhadap bahasanya sebagaimana sikap orang yang lebih tua. Responden yang lebih muda juga menujukkan sikap positif terhadap penggunaan bahasa Slovania di gereja. Dalam segala hal, mereka lebih bersikap positif dengan hal yang berkenaan dengan harapan untuk identitas dan masa depan bahasa Slovania.

Akan tetapi penelitian ini menunjukkan bahwa sikap positif yang ditunjukkan oleh orangtua di kota Palopo tidak memberi kontribusi pada pemertahanan bahasa Luwu. Sebaliknya kondisi bahasa ini sedang mengalami fase bergeser di kalangan anak-anak. Sementara berdasarkan

\footnotetext{
11Jumharia Djamareng, "Factors Contributing to the Maintenance of Balinese Language among Transmigrant Communities in Sukamaju Noth Luwu" (Universitas Hasanuddin, 2012).

${ }^{12}$ Tom Priestly, "Maintenance of Slovene in Carinthia (Austria): Grounds for Guarded Optimism?," Canadian Slavonic Papers 45, no. 1/2 (2003): 95-117.
} 
teori tentang pemertahanan bahasa bahwa indikator pemertahanan bahasa dapat dilihat dari kelompok usia penutur bahasa yang masih menggunakan bahasa yang dimaksud. Jika suatu bahasa masih bisa dituturkan oleh kelompok usia kanak-kanak maka dapat dikatakan bahwa bahasa tersebut masih bertahan sebaliknya jika penutur bahasa adalah kelompoklanjut usia maka bahasa itu bisa dikategorikan bergeser. Hasil penelitian ini didukung oleh Romaine (1989) ${ }^{13}$ yang menemukan bahwa identifikasi pada bahasa dan sikap positif tidak menjamin pemertahanan bahasa tersebut seperti kasus bahasa Inggris yang terjadi di Irlandia.

\section{PENGARUH PERAN ORANGTUA TERHADAP PERGESERAN BAHASA LUWU}

Berdasarkan temuan-temuan yang yang diperoleh dari data kuesioner dan hasil perhitungan persentase, maka dapat dinyatakan bahwa peran orang-tua memberikan pengaruh terhadap pergeseran bahasa Luwu dikalangan anak-anak. Ini berarti tingkat penggunaan bahasa yang dipraktekkan oleh orang-tua ketika mereka berkomunikasi kepada anakanak mereka secara tidak langsung mempengaruhi penguasaan bahasa ibu oleh anak-anak tersebut. Ketika anak-anak terbiasa mendengarkan orangorang yang ada dalam lingkungan mereka menggunakan bahasa ibu sejak dini atau dalam masa pemerolehan bahasa mereka, tentu saja hal ini membentuk kemampuan pemerolehan bahasa pertama pada mereka baik secara aktif maupun pasif.

Akan tetapi, sangat disayangkan bahwa orang-tua yang bermukim di kota Palopo terutama di kecamatan yang termasuk wilayah pusat kota; yaitu kecamatan Wara, kecamatan Wara Timur dan Kecamatan Bara, lebih sering menggunakan bahasa Indonesia dialek Palopo ketika berinteraksi kepada anak-anaknya. Bahkan mereka juga lebih banyak menggunakan bahasa tersebut ketika berkomunikasi dengan orang-lain. Hal ini disebabkan karena kondisi masyarakat di kota Palopo yang multi etnis. Oleh karena itu, kondisi inilah yang menjadi penyebab mengapa masyarakat kota Palopo lebih memilih menggunakan bahasa Indonesia sebagai alat untuk berkomunikasi sehari-hari, sebagaimana yang diperoleh dari hasil wawancara:

" saya ndak setuju menggunakan bahasa daerah karena tidak semua anak-anak dan orang-tua itu orang Luwu asli, jadi lebih baik pakai bahasa baku. Anak-anak juga kurang lancar kalo kita bicara pake bahasa daerah atau mereka nda terlalu respon baik." (hasil wawancara, Oktober 2015)

${ }^{13}$ Romaine, Bilingualism. 


\section{2 | Jumharia Djamareng, Jufriadi}

Adapun alasan orang tua yang bersikap netral terhadap penggunaan bahasa Luwu dalam ranah keluarga adalah sebagai berikut:

"kalo menegur anak-anak pake bahasa daerah kadang mereka tanggapi dengan baik tapi kadang-kadang juga mereka anggap biasa kalo berbahasa Luwu. Jadi saya juga pake bahasa Indonesia biasa supaya dipaham dengan baik." (Hasil wawancara, Oktober 2015)

Sementara responden yang setuju menggunakan bahasa Luwu di rumah dengan anak-anaknya dan dengan orang Luwu lainnya, cenderung berpendapat sama bahwa mereka merasa lebih akrab atau rasa kekeluargaan lebih kental jika menggunakan bahasa daerah mereka.

Berdasarkan data dari hasil wawancara yang menjelaskan bahwa penggunaan bahasa daerah oleh orang-tua kepada anak-anaknya sangat mempengaruhi kemampuan berbahasa daerah mereka. Selanjutnya hal ini secara tidak langsung berpengaruh pada pergeseran bahasa Luwu di kota Palopo.

Hasil penelitian ini didukung oleh teori yang diajukan oleh Sun (2000) ${ }^{14}$ dalam penelitian tentang pemertahanan bahasa pada keluarga imigran Cina dimana peran orang dalam mempertahankan bahasanya sangat signifikan. Hasil penelitian ini juga sejalan dengan hasil yang ditemukan oleh Tannenbaum dan Pauline (2002) ${ }^{15}$ dimana keluarga memegang peran penting dalam mempertahankan anak-anakCina lebih menggunakan bahasa ibu orang tua mereka. Sementara Benjamin (1993) ${ }^{16}$ juga menemukan pentingnya peran keluarga dalam mempertahankan bahasa Spanyol pada anak-anak Meksiko. Sama halnya dengan apa yang ditemukan oleh Bodnitski (2007) ${ }^{17}$ dimana dia juga menyimpulkan bahwa factor yang sangat penting dalam mempertahankan bahasa pertama adalah penggunaan bahasa minoritas dalam kehidupan sehari-hari.

\section{PENUTUP}

Berdasarkan penelitian yang telah dilakukan terlihat bahwa sikap orang tua terhadap bahasa Luwu masih cukup positif berdasarkan data kuesioner dengan menggunakan analisis persentase. Akan tetapi sikap ini tidak memberikan kontribusi pada pemertahanan bahasa Luwu di kota Luwu

14 Sun L, First Language Maintenance in Recent Chinese Immigrant Families (Texas: Texas Tech University, 2000).

15.Michal Tannenbaum and Pauline Howie, "The Association between Language Maintenance and Family Relations: Chinese Immigrant Children in Australia," Journal of Multilingual and Multicultural Development 23, no. 5 (2002): 408-24.

${ }_{16} \mathrm{R}$ Benjamin, The Maintenance of Spanish by Mexicano Children and Its Function in Their School Lives (California: University of California, Berkeley, 1993)..

17 Bodnitski J, First Language Maintenance or Loss: Ukrainian Immigrant Families' Perspectives (Canada: York University, 2007). 
itu sendiri. Data menunjukkan anak-anak di kota Palopo jarang menggunakan bahasa Luwu, bahkan ada beberapa responden yang tidak memahami bahasa tersebut baik secara aktif maupun pasif. Oleh karena itu sikap orang tua tidak berpengaruh pada pergeseran bahasa di kalangan anakanak di kota Palopo. Penggunaan bahasa Luwu oleh orang tua dalam ranah keluarga dapat berpegaruh pada pergeseran maupun pemertahanan bahasa daerah yang umumnya terjadi dikalangan anak- anak meskipun bahasa daerah tersebut dituturkan didaerah asalnya sendiri. Hal ini dibuktikan oleh hasil analisis kuesioner dimana hampir semua jawaban responden menyatakan tidak menggunakan bahasa Luwu dalam berkomunikasi dengan keluarga dan handai taulan maupun orang lain. Ini berarti peran orang tua memberikan pengaruh pada pergeseran bahasa yang dialami anak-anak di kota Palopo.

\section{DAFTAR PUSTAKA}

Benjamin, R. The Maintenance of Spanish by Mexicano Children and Its Function in Their School Lives. California: University of California, Berkeley, 1993.

Cashman, H.R. Doing Being Bilingual: Language Maintenance, Language Shift, and Conversational Codeswitching in Southwest Detroit. United States of America: University of Michigan, 2001.

Chaer, Abdul, and Leonie Agustina. Sosiolinguistik: Perkenalan Awal. Jakarta: PT. Rineka Cipta, 2004.

Chang, M. Language Use and Language Attitudes Among Taiwanese Elementary School Students in Native Language Instruction Programs: A Study on Language Maintenance, Language Shift, and Language Planning in Taiwan. Indiana: Indiana University, 1996.

Chen, S. Language Maintenance and Shift in The Chinese Community of Greater Philadelphia. Penssylvania: University of Pennsylvania, 1992.

Chung, Y.Y. An Analysis of Chinese Parental Attitudes Toward Their Children's Heritage Language Maintenance and Development. California: Biola University, 2007.

Djamareng, Jumharia. "Factors Contributing to the Maintenance of Balinese Language among Transmigrant Communities in Sukamaju Noth Luwu." Universitas Hasanuddin, 2012.

Donitsa-Schmidt, S. Language Maintenance or Shift: Determinants of Language Choice Among Soviet Immigrants in Israel. Canada: University of Toronto, 1999.

Edwards, J. Language, Society, and Identity. London: Basil Blackwell Ltd, 1985. Fasold, R. The Sociolinguistics of Society. England: Basic Blackwell, Inc., 1984.

Holdeman, J.D. Language Maintenance and Shift Among the Russian Old Believers of Erie. Ohio: The Ohio State University, 2002.

J, Bodnitski. First Language Maintenance or Loss: Ukrainian Immigrant Families' Perspectives. Canada: York University, 2007. 


\section{4 | Jumharia Djamareng, Jufriadi}

J, Holmes. Bilingualism. USA: Blackwell Publisher Ltd, 1989.

Kramsch. Language and Culture. London: Cambridge University Press, 1998.

L, Sun. First Language Maintenance in Recent Chinese Immigrant Families.

Texas: Texas Tech University, 2000.

Lawson, Sarah. "Identity, Language Use, and Attitudes: Some SylhetiBangladeshi Data from London, UK." Journal of Language and Social Psychology 23 (2004): 49.

Lenore, A.G, and J.W. Lindsay. "Language Endangerment and Language Maintenance / Language Death and Language Maintenance: Theoretical, Practical and Descriptive." Language 81, no. 4 (2005): 965.

Lukman. "Pemertahanan Bahasa Warga Transmigran Jawa Di Wonomulyo Polmas Serta Hubungannya Dengan Kedwibahahsaan Dan Faktor-Faktor Sosial." Universitas Hasanuddin, 2000.

Lung, B.K.P. Preschool Teachers' Attitudes Toward Children's Native Language Maintenance. Delaware: University of Delaware, 2008.

Machmoed, H. “Distibusi Bahasa Duri Dan Bahasa Toraja Di Daerah Marginal Kecamatan Alla Kecamatan Alla Kabupaten Enrekang Dan Kecamatan Mengkendek Kabupaten Tana Toraja (Suatu Analisis Geografi Dialek)." Universitas Hasanuddin, 2005.

Mahsun. Metode Penelitian Bahasa. Jakarta: PT. Raja Grafindo Persada, 2007.

Marongiu, M.A. Language Maintenance and Shift in Sardinia: A Case Study of Sardinian and Italian in Cagliari. Illinois: University of Illinois, 2007.

Masruddin. "Language Shift of Wotunese: Influenced Ffactors and Its Solution." Universitas Hasanuddin, 2011.

Mestrie, R. Introducing Sociolinguistics. Edinburgh: Edinburgh University Press, 2000.

Moriguchi-McCormick, Y. The Relationship Between Attitudes Toward FirstLanguage Maintenance and First-Language Literacy Skills Among Japanese Children Sojourning in the San Francisco Bay Area. California: University of San Fransisco, 1999.

Priestly, Tom. "Maintenance of Slovene in Carinthia (Austria): Grounds for Guarded Optimism?" Canadian Slavonic Papers 45, no. 1/2 (2003): 95117.

R, Mestrhie. Introducing Sociolinguistics. Edinburgh: Edinburgh University Press, 2000.

Romaine, S. Bilingualism. Massavhusetts: Blackwell Publisher Ltd, 1989.

Salim, A.R. "Attitudes and Psycholinguistic Aspects of First Language Maintenance Among Russian-Jewish Immigrants in Israel." Educational Psychology 19, no. 2 (1999): 133.

Spolsky, B. Sociolinguistics. New York: Oxford University Press, 1998.

Tannenbaum, Michal, and Pauline Howie. "The Association between Language Maintenance and Family Relations: Chinese Immigrant Children in Australia." Journal of Multilingual and Multicultural Development 23, no. 5 (2002): 408-24.

Trudgil, P. Sociolinguistics Variation and Change. Great Britain: Georgetown University Press, 2002.

Wardaugh. Sociolinguistics. Great Britain: Cambridge University Press, 2002. 


\section{Daftar pustaka}

$\operatorname{asda}^{18}$

${ }^{18}$ H.R Cashman, Doing Being Bilingual: Language Maintenance, Language Shift, and Conversational Codeswitching in Southwest Detroit (United States of America: University of Michigan, 2001); M Chang, Language Use and Language Attitudes Among Taiwanese Elementary School Students in Native Language Instruction Programs: A Study on Language Maintenance, Language Shift, and Language Planning in Taiwan (Indiana: Indiana University, 1996); Chaer and Agustina, Sosiolinguistik: Perkenalan Awal; S Chen, Language Maintenance and Shift in The Chinese Community of Greater Philadelphia (Penssylvania: University of Pennsylvania, 1992); Y.Y Chung, An Analysis of Chinese Parental Attitudes Toward Their Children's Heritage Language Maintenance and Development (California: Biola University, 2007); S Donitsa-Schmidt, Language Maintenance or Shift: Determinants of Language Choice Among Soviet Immigrants in Israel (Canada: University of Toronto, 1999); J Edwards, Language, Society, and Identity (London: Basil Blackwell Ltd, 1985); Fasold, The Sociolinguistics of Society; J.D Holdeman, Language Maintenance and Shift Among the Russian Old Believers of Erie (Ohio: The Ohio State University, 2002); J, Bilingualism; A.G Lenore and J.W. Lindsay, "Language Endangerment and Language Maintenance / Language Death and Language Maintenance: Theoretical, Practical and Descriptive," Language 81, no. 4 (2005): 965; Lukman, “Pemertahanan Bahasa Warga Transmigran Jawa Di Wonomulyo - Polmas Serta Hubungannya Dengan Kedwibahahsaan Dan Faktor-Faktor Sosial" (Universitas Hasanuddin, 2000); B.K.P Lung, Preschool Teachers' Attitudes Toward Children's Native Language Maintenance (Delaware: University of Delaware, 2008); H Machmoed, “Distibusi Bahasa Duri Dan Bahasa Toraja Di Daerah Marginal Kecamatan Alla Kecamatan Alla Kabupaten Enrekang Dan Kecamatan Mengkendek Kabupaten Tana Toraja (Suatu Analisis Geografi Dialek)" (Universitas Hasanuddin, 2005); Mahsun, Metode Penelitian Bahasa (Jakarta: PT. Raja Grafindo Persada, 2007); M.A. Marongiu, Language Maintenance and Shift in Sardinia: A Case Study of Sardinian and Italian in Cagliari (Illinois: University of Illinois, 2007); Masruddin, "Language Shift of Wotunese: Influenced Ffactors and Its Solution" (Universitas Hasanuddin, 2011); R, Introducing Sociolinguistics; R Mestrie, Introducing Sociolinguistics (Edinburgh: Edinburgh University Press, 2000); Y Moriguchi-McCormick, The Relationship Between Attitudes Toward First-Language Maintenance and First-Language Literacy Skills Among Japanese Children Sojourning in the San Francisco Bay Area (California: University of San Fransisco, 1999); Romaine, Bilingualism; A.R Salim, "Attitudes and Psycholinguistic Aspects of First Language Maintenance Among Russian-Jewish Immigrants in Israel," Educational Psychology 19, no. 2 (1999): 133; Sarah Lawson, "Identity, Language Use, and Attitudes: Some SylhetiBangladeshi Data from London, UK," Journal of Language and Social Psychology 23 (2004): 49; B Spolsky, Sociolinguistics (New York: Oxford University Press, 1998); L, First Language Maintenance in Recent Chinese Immigrant Families; Tannenbaum and Howie, "The Association between Language Maintenance and Family Relations: Chinese Immigrant Children in Australia"; P Trudgil, Sociolinguistics Variation and Change (Great Britain: Georgetown University Press, 2002); Wardaugh, Sociolinguistics. 